\title{
Impact of Taxation as An Aid to Economic Development in Nigeria: Problems and Prospects. (A Study of South East States in Nigeria)
}

\author{
EHIRIUDU, JUDE ALAOMA (M.Sc MNIM) \\ Department of accountancy, School of financial studies, Institute of management and technology (IMT) Enugu \\ UGBOR, RAPPHEAL OLUCHUKWU (FCA) \\ Department of accountancy, School of financial studies, Institute of management and technology (IMT) \\ ABIA OLUCHI PATIENCE (M .Sc) \\ Department of accountancy, School of financial studies, Institute of management and technology (IMT) Enugu
}

\begin{abstract}
The study examines "The Impact of Taxation as an aid to Economic Development in Nigeria, Problems and Prospects" (A Study of South East States, Nigeria). Simple percentage were used to analyze the response from the distributed questionnaires and ANOVA were used in analyzing the table. In respect to my findings, my main findings is that there are poor tax administration, tax evasion and avoidance were the order of the day. The study revealed that taxation is the main sources of revenue in Nigeria. The study also recommends that public enlightenment on taxation, elimination of loop-wholes in tax laws, computerization of tax records and total reorganization of tax officers in Nigeria tax system enhances tax administration.
\end{abstract}

Keywords: Tax administration, Economic development, Tax management, Tax evasion and avoidance, Tax policies.

DOI: $10.7176 / \mathrm{EJBM} / 12-17-11$

Publication date:June 30th 2020

\section{Introduction}

One of the major function of government in developing countries such as Nigeria is the provision of infrastructural services such as electricity, schools, hospitals, pipe-borne water, good roads and as well as ensure a rise in parcapital income, poverty alleviation to mention a few. For these services to be adequately provided government should have enough revenue to finance them. The tax of financing these enormous responsibilities is one of the major problems facing the government of South East States comprising Abia, Anambra, Ebonyi, Enugu and Imo State. Based on the limited resources of government, there is need to carry the citizens of the states along in formulation of the tax policies on tax payers. Hence the imposition of tax on all taxable individuals and companies/organization to augment government financial position is essential and one of the hallmarks of taxation in the South- East States in Nigeria.

In other to solve the problem of tax avoidances and tax evasion government has made and adopted several form of tax legislations and reforms of the existing ones to restructure tax mechanism and administrations in SouthEast States in Nigeria. These tax legislations include:

Companies income tax decree (CITD), Income tax management ACT (ITMD). All these are targeted towards ensuring a total adherence to tax compliance and discouraging tax evasion and avoidance in her tax administration. Because of this study, the researchers would be concerned with the impact of taxation in South- East States in Nigeria where tax payments are one of the major problems that are facing. Taxation is the main source of revenue to government of South East States because of the following challenges that have confronted administration of effective tax system in this part of the country, they are as follows;

Poor administration of taxation by South East States have adversely affected the growth and development of the local government.

Tax evasion by workers, firms, companies and individuals in the South East States has also incapacitated the local governments and State governments from effectively carrying out its developmental projects in the area.

Lack of effective and efficient implementation of tax system in South East States in Nigeria and their local government has contributed negatively to the enforcement of tax policies by the states which invariably affects the development of the area.

Also Corruption which has eaten deeply into virtually all the sectors of Nigeria economy has also affects smooth and effective tax payment in the South East States. All these reasons above indicate that tax administration in South East States hampered and had contributed negatively to economy of South East States. 


\section{Statement of the Problem}

The study intends solving the following problems with this study;

1. Poor administration of tax system has adversely affected the growth and development in the South East States

2. Tax evasion and avoidance by individuals, workers, firms, companies and some government agencies has incapacitated the effective carrying out of development projects in the South East States.

3. Lack of effective and efficient implementation of tax system in South East States has affected the enforcement of tax policies in the area.

4. Corruption which has eaten deeply into all the facets of the economy is another factor affecting tax administration in South East parts of Nigeria.

\section{Objectives of the Study}

The main objective of the study is "Impact Of Taxation As An Aid To Economic Development In Nigeria Problems And Prospects. A Study Of South East States In Nigeria.

The other specific objectives of the study include the following;

1. To examine how poor administration of taxation has adversely affected growth and development.

2. To show how has tax evasion and avoidance has incapacitated effective developmental projects in the area

3. To find out how lack of effective and efficient implementation of tax system has affected the enforcement of tax policies in the South East State.

Generally, this work is done to find out if tax constitutes the bulk of government revenue and to erase the erroneous impression that it is an exploitation by government for their selfish interest.

\section{Research Question}

1To what extent has poor administration of taxation has adversely affected growth and development?

2 How has tax evasion and avoidance has incapacitated effective developmental projects in the area

3 How has lack of effective and efficient implementation of tax system has affected the enforcement of tax policies in the South East State?

\section{Research Hypotheses}

Ho: Poor administration of taxation has adversely affected growth and development to a high extent.

Ho: Tax evasion and avoidance has aderversly affected developmental projects in the area People reacts negatively to towards tax payment

Ho: lack of effective and efficient implementation of tax system has affected the enforcement of tax policies in the South East State.

\section{REVIEW OF RELATED LITERATURE}

Conceptual framework

Tax is a mandatory financial charge or payment levied or imposed upon a tax payer by government or governmental organizations in order to raise fund for several public expenditures and economic growth of the state. Taxation is form of revenue generation and the second largest forms internally generated fund in Nigeria. It is a well established fact that the main source of fund to government revenue is taxation. Taxation is an instrument used by the government for generating public funds (Anyanwu 2004). It is a required payment imposed by the government on the income, profit or wealth of individuals, group of persons, and corporate bodies . The main purpose of a tax is to enable public sector finance its activities so as to achieve some nation's economic and social goals. It can also be for the purpose of redistribution of wealth to ensure social justice (Ola, 2001). Therefore, taxes can be used as an instrument for achieving both micro and macroeconomic objectives especially in developing countries such as Nigeria. However, Musgrave and Musgrave (2004) comment that the declining level of tax revenue generation in the developing countries makes it difficult to use tax as an instrument of fiscal policy for the achievement of economic development. Some governments like Canada, United States, Netherland, and The United Kingdom have substantially influenced their economic development through tax revenue generated from Company Income Tax. Also, Value Added Tax, and Personal Income Tax, have stabilized through tax revenue (Oluba, 2008). In Africa, natural resources such as income from production sharing, royalties, and corporate income tax on oil and mining companies yield the significant portion of tax revenue (Pfister, 2009). The tax sources are the basic and most reliable sources of government revenue because of their certainty and flexibility characteristics. Certainty characteristic implies that collection of taxes from taxpayers is assured, all other things being equal. Tax collection is not affected by the state of the economy; whether the economy is declining, stagnant or growing. Its flexibility makes it possible for the government to adjust the tax system to suit her desired purpose. 


\section{Taxation in Nigeria}

Different types, forms and classes of taxes exist (Anyaduba, 2004) but the commonest classification in Nigeria is that according to the tax payer categorized as direct or indirect. The direct tax is a levy on personal, corporate income or property. Examples are Personal income tax, company income tax, petroleum profit tax, and capital gains tax. When the imposition is on the price of goods and services, then it is called an indirect tax. Indirect tax is payable on the consumption of products and services associated with import duties/tariffs, export duties, value added tax and excise duties. In Nigeria, the government can emphasize on any one of the tax forms depending on the objective it wants to pursue. In Nigeria, different legislations that allow the government tax its citizens and to increase the tax revenue of the country exist. These legislations are the Personal Income Tax Amendment Act 2011, Companies Income Tax Amendment Act 2007, the Petroleum Profit Tax Amendment Act 2004. Others are the Capital Gains Tax Amendment Act 2004, the Value Added Tax Amendment Act 2007 and the Education Tax Amendment Act 2004. The agency of the federal government in charge of the administration and collection of these taxes, (except customs/excise duties) up to April 2007 was the Federal Board of Inland Revenue (FBIR). In 2007, the board was scrapped and replaced by the Federal Inland Revenue Services (FIRS). Nigeria has recorded an increase in tax revenue above the target every year. The Federal Inland Revenue Service (FIRS) reported taxation increased from N2.83 trillion to N4.71 trillion between 2010 and 2014. These figures do not include those taxes collected by tax authorities in the State Board the Local Government Revenue Committee (LGRC). The chart in figure 1below shows the target and actual tax revenue collected from 2000 to 2014.

\section{The nature and scope of taxation}

Taxation is a compulsory but non-penal levy by the government through its agent on the profits, income, or consumption of its subjects or citizens. It is also viewed as a compulsory and obligatory contribution made by individuals and organization towards defraying the expenditure of government (Dandago and Alabede 2001). Kotler (1975) posits that it is a charge levied by the government on the income or wealth of a person or corporate organization for the common benefit of all. The term does not include specific charges made against a particular person or properties for current or permanent benefits and privileges accruing only to those paying such charges. Similarly, Ogundele (1999) defines taxation as the transfer of real economic resources from private sector to the public sector to finance public sector activities. It may be inferred from the foregoing that taxation is the transfer of financial resources from private economic agents like households and corporate bodies, to the public sector to finance the development of the society. Going by the definition of taxation, Nzotta (2007) identified four key issues which must be understood for taxation to play its functions in any society. First, a tax is a compulsory contribution made by the citizens to the government and this contribution is for general common use. Secondly, a tax imposes a general obligation on the tax payer. Thirdly, there is a presumption that the contribution to the public revenue made by the tax payer may not be equivalent to the benefits received. Finally, a tax is not imposed on a citizen by the government because it has rendered specific services to him or his family. Thus, it is evident that a good tax structure plays a multiple role in the process of economic development of any nation which Nigeria is not an exception (Appah, 2010).

The main purpose of tax is to raise revenue to meet government expenditure and to redistribute wealth and management of the economy (Ola, 2001; Jhingan, 2004; Bhartia, 2009). Anyanwu (1993) pointed out that there are three basic objectives of taxation. These are to raise revenue for the government, to regulate the economy and economic activities and to control income and employment. Also, Nzotta (2007) noted that taxes generally have allocation, distributional and stabilization functions. The allocation function of taxes entails the determination of the pattern of production, the goods that should be produced, who produces them, the relationship between the private and public sectors and the point of social balance between the two sectors. The distribution function of taxes relates to the manner in which the effective demand over economic goods is divided, among individuals in the society. According to Musgrave and Musgrave (2006), the distribution function deals with the distribution of income and wealth to ensure conformity with what society considers a fair or just state of distribution. The stabilization function of taxes seeks to attain high level of employment, a reasonable level of price stability, an appropriate rate of economic growth, with allowances for effects on trade and on the balance of payments. Nwezeaku (2005) argues that the scope of these functions depends, inter alia, on the political and economic orientation of the people, their needs and aspirations as well as their willingness to pay tax. Thus the extents to which a government can perform its functions depend largely on the ability to design tax plans and administration as well as the willingness and patriotism of the governed Tax is discriminatory in the sense that it is assessed on persons or property based on profits/incomes or gain, the benefit derived by citizens from tax payment is without reference to the contribution of individual tax payers (Nightingale, 2000). In line with this, Ariwodola (2000) posits that it is accurate to say that the primary objective and purpose of taxation in most nations of the world is essentially to generate revenue for government expenditure on social welfare such as provision of defence, law and order, health services and education. Tax revenue can also be expended on capital projects otherwise called consumer expenditure, creating social and economic infrastructure which will improve the social life of the people 
(Angahar \& Alfred, 2012). Other than facilitating the administrative function of government, taxation as the most potential source of revenue to the government of any nation, has played very crucial roles as an instrument of governmentes economic, social and fiscal policy. Taxation is used for the purpose of discouraging certain forms of anti-social behaviour in the society. Taxation according to Musgrave and Musgrave (1980) can be extensively used in regulating the consumption pattern resulting in economic stabilization. Anti-social behaviour such as drinking of alcohol, smoking and pool betting can be controlled by imposition of higher taxes on production of such goods.

\section{Nature of the Nigerian Economy}

Nigeria is one of the largest geographical units in West Africa and occupies a land area of 923,768 square kilometers. Nigeria lies within the tropics with two main vegetation zones. The rain forest and Savannah zones reflect the amount of rainfall and its spatial distribution. The three broad sectors of the Nigerian economy are primary/agriculture/natural resources, secondary processing and manufacturing, and tertiary/services sectors. Two sectors dominated the Nigerian economy namely, agriculture and crude oil petroleum. In the 1960s and early 1970s, the primary revenue earner was agriculture and from the late 1970s to date, it has been the oil sector. Agriculture was the core driving force of economic activities then, followed by manufacturing and mining activities at very low levels of development (Apata 2011). From the early 1970s, the Federal Government of Nigeria started experiencing an immense increase in revenue derived from crude oil. This sudden wealth from crude oil was invested in socio-economic infrastructures across the country especially in the urban cities, resulting in the growth of the country's service sector at a very high rate. The investment in the socio-economic infrastructure led to a migration of young men and women from the hinterland to the urban cities thus expanding the oil-driven urban economy. This drastic migration led to the collapse of the agricultural sector as oil became Nigeria's primary source of revenue. Only the aged in the village engaged in agricultural business activities

\section{Theoretical framework}

This study is based and reviewed on three theories of taxation: the cost of service theory, the benefit theory and the sociopolitical theories of taxation. According to the cost of service theory, the cost incurred by government in providing certain services to the people must collectively be met by the people who are that receivers of the service, this is in the words of (Jhingan, 2009). This theory articulated that tax is similar to price. So if a person does not utilize the service of a state, he should not be charged any tax. Some criticisms have been leveled against this theory. According to Jhingan (2009), the cost of service theory imposes some restrictions on government services. The objective of government is to provide welfare to the poor. If the theory is applied, the state will not undertake welfare activities like medical care, education, social amenities, etc. furthermore, it will be very difficult to compute the cost per head of the various services provided by the state, again, the theory has violated the correct definition and tenets of tax, finally the basis of taxation as propounded by the theory is misleading. The limitations inherent in the cost of service theory led to the modernization of the theory. This modification gave birth to the benefit received theory of taxation. According to this theory, citizens should be asked to pay taxes in proportion to the benefits they receive from the services rendered by the government. The theory assumes that there is exchange relationship or quid pro quo between tax payers and government. The government confers some benefits on tax payers by providing social goods which the tax payers pay a consideration in the form of taxes for using such goods. The inability to measure the benefits received by an individual from the services rendered by the government has rendered this theory inapplicable (Ahuja, 2012). The socio-political theory of taxation states that social and political objectives should be the major factors in selecting taxes. The theory advocated that a tax system should not be designed to serve individuals, but should be used to cure the ills of society as a whole (Bhartia, 2009). This study is therefore anchored on this theory.

\section{Empirical studies:}

Several empirical studies have been conducted on the impact of taxes on economic growth. Okafor (2012) investigated the impact of income tax revenue on the economic growth of Nigeria as proxied by the gross domestic product (GDP). The study adopted the ordinary least square (OLS) regression analysis technique to explore the relationship between the GDP (the dependent variable) and a set of federal government income tax revenue heads over the period 1981-2007. The regression result indicated a very positive and significant relationship between the components of tax revenue and the growth of the Nigeria economy. Adereti, Sanni and Adesina (2011) studied value added tax and economic growth in Nigeria. Time series data on the Gross Domestic Product (GDP), VAT Revenue, Total Tax Revenue and Total (Federal Government) Revenue from 1994 to 2008 sourced from Central Bank of Nigeria $(\mathrm{CBN})$ were analyzed, using both simple regression analysis and descriptive statistical method. 


\section{METHODOLOGY}

\section{Research Design}

The study is a simple data selected from all the five states that made South East States namely Abia State, Anambra State, Ebonyi State, Enugu State and Imo State of Nigeria. A letter of introduction containing the research topic and purpose of the study was given to the States concerned. During the course of the research, the researcher carried out the field study on their activities. The primary field study was aimed at finding out the various way in which taxation is employed. To achieve this aim, various research techniques and strategies were used by the researcher to carry out the study in an organized manner to arrive at his conclusion. The investigation strategy the researcher adopted at its preliminary study were oral interviews, observations and distributed questionnaire to some employees or staff and few top management officials including the accountant, employees of the state and federal board of the internal revenue services.

Area of the Study The study was carried out in South East States in, Nigeria, to determine the several impact created by taxation, problems and its possible solution South East States and Nigeria at large.

Population of the Study Population as used here implies the totality of all the items we set out to study. It is the target group from which data is collected, analysis and conclusion drawn. For the purpose of this research work, the population under study is;

a. Employees of the State and federal board of the inland revenue and state ministry of finance of all South East States

b..Iindividual and incorporate bodies.

c. Professionals mainly from the private sector of economy

\section{Sample Method}

A sampling is usually required from a chosen population for the sake of this work. The sample size of this persons includes employees of the federal board of Revenue Services, Tax payers and professionals. There are fifty all [sampling size $=50$ ]

Sampling size can be small or large. The decision to choose small or larger will depend on the following;
a. The need for the researcher
b. The time available for the study
c. The cost involved.
d. The sample size as the ensure representation

\section{Sources of Data}

In collection of data this research work, wide spectrum of research instruments were used. These embrace questionnaires, interview and library research.

\section{Method of Data Analysis}

The method that analysis data or the result information are the standard deviation chi-square. The use of percentage, using of tables. Conclusively, in the analysis of data of this study, in this research, the research believes on the reliability, validity, constituency, testable and experimental, in compliance with the assumption made earlier in the previous chapters.

\section{Presentation and Analysis of Data}

The presentation of data as expressed is based on the design of the questionnaire. In this chapter the presentation and analysis of data which is based on the whole questionnaire being distributed. The questionnaire indicates the effectiveness of the Nigeria tax system based on the answer provided by the respondents. The presentation takes from tabulation with the use of pie chart and the analysis take data from the completed questionnaires.

\section{Hypothesis One}

$\mathrm{H}_{1}$ : Poor administration of taxation in South East States has not adversely affected growth and development to high extent.

Ho: : Poor administration of taxation in South East States has adversely affected growth and development to high extent.

Table 1. Model Summary

\begin{tabular}{|l|c|r|r|r|r|}
\hline Model & \multicolumn{1}{|c|}{$\mathrm{R}$} & R Square & Adjusted R Square & Std. Error of the Estimate & Durbin-Watson \\
\hline 1 & $.751^{\mathrm{a}}$ & .565 & .440 & .22348 & 0.028 \\
\hline
\end{tabular}

Source: SPSS Version 22

a. Predictors: (Constant), CIT, PIT 
Table 2. ANOVA ${ }^{\mathrm{a}}$

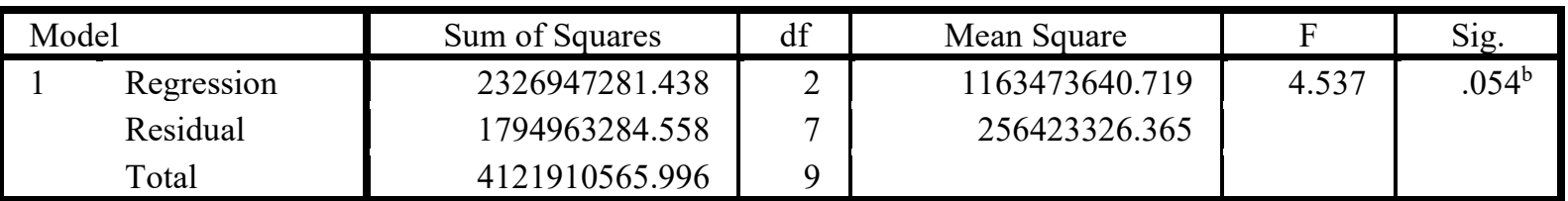

Source: SPSS Version 22

a. Dependent Variable: GDP @ Current market value

b. Predictors: (Constant), CIT, PIT

Table 3. Coefficients ${ }^{\mathrm{a}}$

\begin{tabular}{|c|c|c|c|c|c|c|}
\hline \multirow{2}{*}{\multicolumn{2}{|c|}{ Model }} & \multicolumn{2}{|c|}{ Unstandardized Coefficients } & \multirow{2}{*}{$\frac{\text { Standardized Coefficients }}{\text { Beta }}$} & & \multirow[b]{2}{*}{ Sig. } \\
\hline & & $\mathrm{B}$ & Std. Error & & & \\
\hline & (Constant) & 11162.654 & 9313.776 & & 1.199 & .270 \\
\hline & PIT & -472.365 & 1033.287 & -.418 & -.457 & .661 \\
\hline & CIT & 66.312 & 52.986 & 1.145 & 1.252 & .251 \\
\hline
\end{tabular}

Source: SPSS Version 22

a. Dependent Variable: GDP @ Current market value

A linear regression analysis conducted to examine the extent government has been using revenue generated by tax. (table 1-3) shows that there is strong positive relationship between government revenue generation and tax $(\mathrm{R}$ - coefficient $=.751)$. The $\mathrm{R}$ square, the coefficient of determination, shows that only $56.5 \%$ of the variation in government revenue generation can be explained by tax with no autocorrelation as Durbbin-Watson $(0.028)$ is less than 2. With the linear regression model, the error of estimate is low, with a value of about .22348. The regression sum of the square 2326947281.438 is more than the residual sum of the square 1794963284.558 indicating that the variation is not due to chance. The F-statistics $=4.537$ shows that the model is significant.

\section{Decision Rule}

Reject null hypothesis (Ho) if $\mathrm{P}-$ Value $<0.05$ and do not reject Ho if otherwise

\section{Decision}

Since the P-Value $000<0.05$, we reject the null hypothesis (Ho) and then conclude that government to a high extent has been using revenue generated by tax.

\section{Hypothesis Two}

$\mathrm{H}_{1}$ : Tax evasion and avoidance has not incapacitated effective developmental projects in South East States in Nigeria

Ho: Tax evasion and avoidance has incapacitated effective developmental projects in South East States in Nigeria

Table 4. Model Summary

\begin{tabular}{|l|r|r|r|r|r|}
\hline Model & \multicolumn{1}{|c|}{ R } & R Square & Adjusted R Square & Std. Error of the Estimate & Durbin-Watson \\
\hline 1 & $.623^{\mathrm{a}}$ & .389 & .312 & 2263.63111 & 0.072 \\
\hline
\end{tabular}

Source: SPSS Version 22

a. Predictors: (Constant), VAT

Table 5. ANOVA ${ }^{\mathrm{a}}$

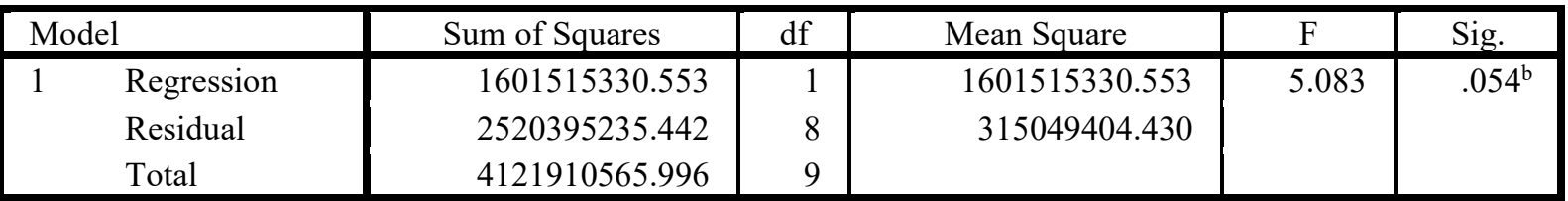

Source: SPSS Version 22

a. Dependent Variable: GDP @ Current market value

b. Predictors: (Constant), VAT 
Table 6. Coefficients ${ }^{\mathrm{a}}$

\begin{tabular}{|c|c|c|c|c|c|}
\hline \multirow[b]{2}{*}{ Model } & \multicolumn{2}{|c|}{ Unstandardized Coefficients } & \multirow{2}{*}{$\frac{\text { Standardized Coefficients }}{\text { Beta }}$} & \multirow[b]{2}{*}{$\mathrm{T}$} & \multirow[b]{2}{*}{ Sig. } \\
\hline & $\mathrm{B}$ & Std. Error & & & \\
\hline (Constant) & 11251.448 & 11790.912 & & .954 & .368 \\
\hline VAT & 51.857 & 23.000 & .623 & 2.255 & .054 \\
\hline
\end{tabular}

Source: SPSS Version 22

a. Dependent Variable: GDP @ Current market value

A linear regression analysis conducted to determine the reaction of people towards tax payment (table 4 - 6 .) shows that there is strong negative relationship people's reaction and tax payment $(\mathrm{R}$ - coefficient $=.623$ ). The $\mathrm{R}$ square, the coefficient of determination, shows that only $38.9 \%$ of the variation in tax payment can be explained by peoples' reaction with no autocorrelation as Durbbin-Watson (.072) is less than 2. With the linear regression model, the error of estimate is high, with a value of about 2263.63111. The regression sum of the square 1601515330.553 is less than the residual sum of the square 2520395235.442 indicating that the variation is due to chance. The F-statistics $=5.083$ shows that the model is insignificant.

Decision Rule :Reject null hypothesis (Ho) if P-Value $<0.05$ and do not reject Ho if otherwise

\section{Decision}

Since the P-Value $000<0.05$, we reject the alternate hypothesis $\left(\mathrm{H}_{1}\right)$ and then conclude that people do not react positively to towards tax payment

\section{Hypothesis Three}

$\mathbf{H}_{1}$ : Lack of effective and efficient implementation of tax system has not affected the enforcement of tax in South East States..

Ho: : Lack of effective and efficient implementation of tax system has affected the enforcement of tax in South East States..

Table 7. Model Summary

\begin{tabular}{|l|r|r|r|r|r|}
\hline Model & $\mathrm{R}$ & R Square & Adjusted R Square & Std. Error of the Estimate & Durbin-Watson \\
\hline 1 & $.405^{\mathrm{a}}$ & .164 & .060 & 20752.36676 & 0.75 \\
\hline
\end{tabular}

Source: SPSS Version 22

a. Predictors: (Constant), PPT

Table 8. ANOVA ${ }^{\mathrm{a}}$

\begin{tabular}{|ll|r|r|r|r|r|}
\hline \multicolumn{2}{|l|}{ Model } & Sum of Squares & df & Mean Square & F & Sig. \\
\hline 1 & Regression & 676624756.456 & 1 & 676624756.456 & 1.571 & $.245^{\mathrm{b}}$ \\
& Residual & 3445285809.540 & 8 & 430660726.192 & & \\
Total & 4121910565.996 & 9 & & & \\
\hline
\end{tabular}

Source: SPSS Version 22

a. Dependent Variable: GDP @ Current market value

b. Predictors: (Constant), PPT

Table 9. Coefficients ${ }^{\mathrm{a}}$

\begin{tabular}{|c|c|c|c|c|c|}
\hline \multirow[b]{2}{*}{ Model } & \multicolumn{2}{|c|}{ Unstandardized Coefficients } & \multirow{2}{*}{$\begin{array}{c}\text { Standardized Coefficients } \\
\text { Beta }\end{array}$} & \multirow[b]{2}{*}{$\mathrm{T}$} & \multirow[b]{2}{*}{ Sig. } \\
\hline & $\mathrm{B}$ & Std. Error & & & \\
\hline $\begin{array}{ll}1 & \text { (Constant) } \\
& \text { PPT }\end{array}$ & $\begin{array}{r}17983.122 \\
9.943\end{array}$ & $\begin{array}{r}14813.938 \\
7.933\end{array}$ & .405 & $\begin{array}{l}1.214 \\
1.253\end{array}$ & $\begin{array}{l}.259 \\
.245\end{array}$ \\
\hline
\end{tabular}

Source: SPSS Version 22

a. Dependent Variable: GDP @ Current market value

A linear regression analysis conducted to find out if tax revenue is the most effective source of government revenue. (table 7-9) shows that there is strong negative relationship between tax revenue and government revenue $(\mathrm{R}$ - coefficient $=.405)$. The $\mathrm{R}$ square, the coefficient of determination, shows that only $16.4 \%$ of the variation in government can be explained by tax revenue with no autocorrelation as Durbbin-Watson (.075) is less than 2. With the linear regression model, the error of estimate is high, with a value of about 20752.36676. The regression sum of the square 676624756.456 is less than the residual sum of the square 3445285809.540 indicating that the variation is due to chance. The F-statistics $=1.571$ shows that the model is insignificant. 
Decision Rule

Reject null hypothesis (Ho) if $\mathrm{P}-$ Value $<0.05$ and do not reject Ho if otherwise

\section{Decision}

Since the P-Value $000<0.05$, we reject the alternate hypothesis $\left(\mathrm{H}_{1}\right)$ and then conclude that tax revenue is not the most effective source of government revenue.

\section{Summary of the Findings}

The main objective of the study is 'Impact Of Taxation As Aid To Economic Development In Nigeria; Problems And Prospects.( A Study Of South East States Nigeria).

Other specific objectives of the study indicates the following as the findings of the study;

a. That poor administration of taxation in South East States have adversely affected growth and development in that part of Nigeria

b. Tax evasion and avoidance has incapacitated effective developmental projects as a result of none payment of tax in the South East region.

c. Lack of effective and efficient implementation of tax system has affected the enforcement of tax policies in the States of South East Nigeria.

\section{Findings}

Other research findings reviewed that the system of tax administration is deficient which can encourage tax evasion and avoidance. This basically because of operation hardware lack of honest and trained revenue officers.

In addition to above research findings, some problem connected with the Nigeria tax system were identified.

\section{Conclusion}

Effort has been made on this study to examine the impact of taxation as an aid to the economic development various data where gathered and analysis to determined the reliability of formulated hypothesis.

The study showed that in South East States, taxation is the most significant source of revenue in (Nigeria) it is noted that taxation the second most significant source of government revenue after crude oil Nigeria. This is the most reason while taxation should be taken more seriously.

The study further discussed the problem of poor tax administration in Nigeria, this occurred as result of poor tax administration, incessant tax evasion, tax avoidance and high level of corruption among the tax officers in the states and lack of trained and qualified revenue official.

The result of the findings has revealed that tax is a 'sine qua none' for the growth and development and Nigeria cannot survive without a sound taxation tax administration system in the country at large.

\section{Recommendation}

Going by the findings of the researchers, the following suggestion and recommendations made which we believed could increase tax revenue as well as eliminate administrative problems in tax administration South East part of Nigeria.

1. The tax officials needs improvement through adequate training and provision of suitable working materials and facilities

2. Government should distribute its social welfare programmes in such a way as to provide direct benefit to tax payers. This makes them believe that the portion of their hard earned money paid for a purpose is effectively utilized by the government.

3. There should be a public enlightenment campaing by the government aimed towards emphasizing on the importance and need to pay taxes and when due unless people know what is expected of them in the form of tax contribution and money will be lost to the treasury's as a result of ignorance.

4. It is suggested that all of us should eschew corruption in all its fact and pursue virtue. Our tax law should statue should be reveiew so as to block the loopholes of evasion and avoidance. We should all salvage our great country.

5. Full computerization of records of the inland revenue department should be in place in order to be able to make assessment, have quick access to tax payers personal file and provide data for decision making

6. The modes operand for the assessment and collection of taxes by revenue staff should be reorganized such that.

a. A revenue intelligent section should be established in each revenue office charged with the specialized responsibility of investigating information field return. They should answer that subjectivity in the application of tax laws by the tax officials is 
reduced.

b. Mobile revenue courts should be established to asset in collecting assesses taxes from individuals and employees using "operation show your tax receipts" system and prosecuting defaulters.

c. Financially, the activities of in land revenue department should be audited amnesty by external to ensure proper accountability control of fraudulent practices and careless errors in making assessment and ensuring efficient revenue collection.

Conclusively is believe that the above mentioned recommendation of taxes will be achieved. Then the impact of taxation as an aid to economic development in South East State (Nigeria) will be felt by all.

\section{Reference}

Adam Smith, (2015). The Wealth of Nations: A Translation into Modern English, ISR/Google Books,. Book 5 (Government Finances: Public Expenditure, Taxation and Borrowing), pages 423, 429. Ebook ISBN 9780906321706

Samuelson, Paul A. (2012)"Diagrammatic Exposition of a Theory of Public Extpenditure" (PDF). University of California, Santa Barbara.

Erik Robert Lindahl (2012).Encyclopædia Britannica. 1960-01-06. Retrieved -08-27.

Ademola Idowu (2012)"Theories of Taxation - Benefit Theory - Cost of Service Theory - Ability to Pay Theory - Proportionate Principle". Economicsconcepts.com.

Giersch, Thorsten (2007). "From Lindahl's Garden to Global Warming: How Useful is the Lindahl Approach in the Context of Global Public Goods?" (PDF).

Friedman, David D. (2012). "Price Theory: an intermediate text". South-Western Publishing Co. ISBN 9780538805643. Archived from the original on November 23, 2012

Oluba, M.N. (2008):“Justifying Resistance to tax payment in Nigeria”, Economic Reflections Volume B, No 3, April.

Osoro, N.E.(1991): “Tax Reform in Tanzania: Motivations, Directions and Implications”. A progress Report presented to the African Economic Research Consortium. Nairobi, Kenya, 26-30 May.

Owolabi S. A and A. T. Okwu(2011): "Empirical Evaluation of Contribution of Value Added Tax to

Development of Lagos State Economy", Middle Eastern Finance and Economics.

Padovano, F and G. Emma (2001): "Tax rates and economic growth in the OECD countries (1950-1990)", Economic Inquiry, 39, 44-57 (January).

Pfister, M (2009): “Taxation for Investment and Development: An Overview of Policy Challenges in Africa', Ministerial Meeting and Expert Roundtable of the NEPAD-OECD Africa Investment Initiative on November, $11-12$

Salami, A (2011): “Taxation, Revenue Allocation and Fiscal Federalism in Nigeria: Issues, Challenges and Policy Options", Economic Annals, Volume LVI, No. 189.

Sanni, A (2011): "Nigeria-Recent Developments in Company Income Taxation in Nigeria", Bulletin for International Taxation, 65(1).

Talvi E. and C. A. Végh (2005):"Tax base variability and Pro-cyclical Fiscal Policy in Developing Countries", Journal of Development Economics, 78, 156-190.

Tax Justice Network (TJN) (2005): Aid, Tax and Finance for Development

Thornton, J.(2008): "Explaining Procyclical Fiscal Policy in African Countries", Journal of African Economies, $17,451-464$

Tosun, M.S. and S. Abizadeh(2005): "Economic Growth and Tax Components: An Analysis of Tax Change in OECD”, Applied. Economics., 37: 2251-2263.

United Nations (2000): "Resource Mobilization for Economic Development: The Role of Tax Administrator", United Nations study in conjunction with Association de Planification Fiscale Financiere.

United Nations (2005): Investing in Development, New York: United Nations.

Upender, M. (2004): Applied Econometrics, 2nd Edition, Vrinda Publication Ltd, Delh 